identifying the included insects in this pale amber, came to the conclusion "that this light amber (or copal) is of very recent origin, not earlier than Pleistocene, and contains a fauna which doubtless consists mainly (at least) of species still living." The point of great interest to me is that among these representatives of still living species he found "a small bee which seems not to differ at all from the common living Trigona laviceps Smith."

Now Trigona laviceps, or, as it is sometimes called, Melipona leviceps, is the actual, or at least chief, source of the common resinous substance known as Dammar (Burmese-Pwé-nyet). These bees build in hollows within trees, crevices among rocks, etc., and line the interior surfaces of their nests with a massive resinous substance. This resinous substance is the common Dammar of the Burmese bazaars, and is used largely by the Burmese for the caulking of boats. Hooper (Rep. Labor. Ind. Mus., I904-5, 23-4) reports on two samples examined by him. It seems to be the general opinion that it is largely constructed by the bees from the oil and resin of Dipterocarpus.

It seems to me, therefore, that the light amber beads examined by Prof. Cockerell may quite likely be fossil Dammar, or in other words, Dammar deposited in crevices and holes in the earth or rocks by Melipona, which has afterwards been buried up and entombed and fossilised. The inclusion of a specimen of the actual bee in this fossil Dammar would be not only possible but highly probable if such is the case.

Although I do not know the place from which the pale Chinese amber comes, I offer the above suggestion as to its origin; and from what I saw of the actual occurrence of the Burmese amber in the Hukong Valley amber mines it seems to me not unlikely that some such method may be the explanation of its origin also, though in this case one would not , expect the depositing insect to be the same species as that depositing Dammar at the present day. MURRAY STUART.

Indo-Burma Oilfields, Ltd., Thayetmyo, Burma, December 8.

\section{Modern Psilotaceæ and Archaic Terrestrial Plants.}

With the establishment of an early Devonian group of vascular cryptogams showing fundamental resemblances with the modern Psilotaceæ, the controversy over the essentially primitive or reduced nature of the latter family may be said to be closed. In spite of important points of difference, the resemblances appear to suffice to link the Psilotaceæ with the most archaic types of terrestrial plants of which the structure is known at all adequately. The object of the present note is to record another piece of evidence pointing in the same direction.

As Kidston and Lang say, "In its anatomy Asteroxylon is most closely comparable with the Psilotaceæ and with Lycopodium" ("Old Red Sandstone Plants," etc., Part III., I920, p. 667). So far as the leafy shoot is concerned, however, the hollow stele of the Psilotaceæ, as generally described, does not readily fall into line with that of Asteroxylon or Lycopodium, in which the centre is occupied by a more or less compact mass of cauline xylem. It is therefore of some interest to note that one or more cauline strands devoid of protoxylem are normally present in the pith of Tmesipteris Vieillardi Dang., an erect terrestrial form said to be endemic in New Caledonia. The medullary strands generally arise from the ring of peripheral strands in the transitional region between the rhizome and aerial shoot, and when traced distally as a rule end blindly in the pith, although they sometimes merge into the peripheral strands. They show a good deal of variation in the degree of their development, generally not extending very far up into the leafy shoot, but their presence is a normal feature of the anatomy.

In this respect, therefore, Tm. Vieillardi facilitates the comparison of the Psilotaceæ with the Devonian genus Asteroxylon, and also serves to strengthen their lycopod affinity, already established on other grounds. In a paper read before the Cambridge Philosophical Society (see NATURE, June I3, I9I8, vol. Ior, p. 299) I directed attention to this and other features, in view of which I regarded $T \mathrm{~m}$. $V$ ieillardi as the most primitive member of the Psilotaceæ; but the discovery of Asteroxylon adds point to the conclusion there arrived at. It is natural to regard the poorly developed and variable medullary xylem of Tm. Vieillardi as a stage in the disintegration of a once continuous and solid cylinder of cauline xylem extending throughout the length of the axis; the hollow steles of Tm. tannensis and of Psilotum would thus form the next stage in the reduction. This reduction within the group, however, need not affect the essentially primitive nature of the Psilotaceæ as a whole.

I must add that medullary xylem had previously been recorded in Tmesipteris on two occasions: (i.) by C. E. Bertrand, 1885, "Recherches sur les Tmésiptéridées," p. 248, Fig. 2I5 (A); and (ii.) by P. A. Dangeard, Le Botaniste, I890-9I, p. I7, P1. XI. Fig. I. But the nature of the material at their disposal (herbarium specimens) appears to have precluded a detailed investigation by the French authors; they make only a passing reference to the feature in question, apparently considered by them to be only a rare occurrence.

Botany Department,

University of Lucknow, India, December 7 .

\section{Action of Cutting Tools.}

IT is true, as Prof. Andrade points out in NAture of December 30 (vol. IIo, p. 876), that I am " not altogether familiar with the work that has already been done on the subject" : indeed it is obvious. And after glancing through the 82 pages of bibliography at the end of Prof. E. C. Bingham's "Fluidity and Plasticity," I feel certain that I shall remain in this state. Tresca's Memoirs, however, are very well known among engineers, and they have been quoted and digested by several writers of engineering text-books and papers, but it is doubtful if the practical use of cutting tools has been much influenced by Tresca's work, beautiful and interesting though it is.

The important problem which faces the user of cutting tools is the preservation of the cutting edge under heavy loads, and while Taylor's work is the outstanding contribution on the matter, Mr. Mallock's explanation of the influence of friction on the upper surface of the tool is invaluable to the machinist. The study of the shaving, while perhaps uninteresting to the physicist, is vitally important to the engineer, for, on one hand, the machinist watches the behaviour of the tool very much in the shaving, and, on the other, the plastic flow on the back of the shaving, which produces flat-backed shavings from round-nosed tools, is probably a principal cause of the undesirable heating of the tool, and an important factor in the frictional phenomena involved.

H. S. ROWELL, Director of Research.

Research Association of British Motor and Allied Manufacturers,

I5 Bolton Road, W.4, January 4. 